\title{
Description of six autochthonous cases of canine visceral leishmaniasis diagnosed in Pedregulho (São Paulo, Brazil)
}

\author{
Descrição de seis casos autóctones de leishmaniose visceral canina, \\ diagnosticados em Pedregulho (São Paulo, Brasil) \\ Cássia Regina de Abreu'; Ana Cláudia Parpinellii'; Romeika Reis de Lima²; \\ Luis Gustavo Gosuen Gonçalves Dias ${ }^{3}$; Lucas de Freitas Pereira ${ }^{4}$; Fernanda Gosuen Gonçalves Dias ${ }^{4 *}$
}

\author{
${ }^{1}$ Clínica Veterinária São Francisco, Franca, SP, Brazil \\ ${ }^{2}$ Curso de Pós-Graduação em Dermatologia Veterinária, Equalis Ensino e Qualificação Superior, Natal, RN, Brazil \\ ${ }^{3}$ Departamento de Clínica e Cirurgia Veterinária, Faculdade de Ciências Agrárias e Veterinárias, \\ Universidade Estadual Paulista - UNESP, Jaboticabal, SP, Brazil \\ ${ }^{4}$ Universidade de Franca - UNIFRAN, Franca, SP, Brazil
}

Received October 14, 2014

Accepted November 5, 2014

\begin{abstract}
Visceral leishmaniasis is an infectious disease of chronic, emerging and zoonotic nature that presents various degrees of severity. In Brazil, this illness is caused by Leishmania infantum (Leishmania chagasi), which is transmitted by the bite of the sand fly Lutzomyia longipalpis, and dogs are its main reservoir. Given the increasing spread of this disease across Brazil, the aim of this study was to report on six cases of canine visceral leishmaniasis, diagnosed in June 2013, in the city of Pedregulho, State of São Paulo, considered to be a non-endemic area and free of phlebotomine sand flies. The diagnosis was based on clinical signs of the patients and additional tests (serological and parasitological). It was concluded that the diagnosis of leishmaniasis is complex because the clinical signs are similar to other systemic diseases, thus justifying the importance of parasitological test of bone marrow, considered "gold standard", in the confirmation of the disease. In addition, the area was not, until now, considered risk place, despite notification.
\end{abstract}

Keywords: Dog, dermatopathy, Leishmania infantum, protozoa, zoonosis.

\section{Resumo}

A leishmaniose visceral é uma doença infecciosa de caráter crônico, emergente e zoonótico, apresentando variados graus de severidade. No Brasil, tal enfermidade é causada pela Leishmania infantum (Leishmania chagasi), a qual é transmitida pela picada de flebótomo Lutzomyia longipalpis, tendo o cão como o principal reservatório. Perante a crescente distribuição da doença no território brasileiro, o objetivo do presente trabalho é relatar seis casos de leishmaniose visceral canina, diagnosticados em Junho de 2013, no município de Pedregulho, Estado de São Paulo, considerado área não endêmica e livre de flebotomíneos. O diagnóstico foi baseado nos sinais clínicos dos pacientes e exames complementares (sorológicos e parasitológicos). Concluiu-se que o diagnóstico da leishmaniose é complexo pelo fato dos sinais clínicos serem semelhantes a outras enfermidades sistêmicas, justificando assim a importância do teste parasitológico de medula óssea, considerado "padrão ouro" na confirmação da doença. Além disso, a área não foi, até o presente momento, considerada local de risco, apesar da notificação.

Palavras-chave: Cão, dermatopatia, Leishmania infantum, protozoário, zoonose.

\section{Introduction}

The leishmaniases are a group of diseases caused by more than thirty species of the genus Leishmania, many of which are anthropozoonoses (FERREIRA et al., 2012). The parasites

*Corresponding author: Fernanda Gosuen Gonçalves Dias. Universidade de Franca - UNIFRAN, Av. Dr. Armando Salles de Oliveira, 201, Parque

Universitário, CEP 14404-600, Franca, SP, Brasil.

e-mail: fernandagosuen@yahoo.com.br are obligate intracellular protozoa and are transmitted to hosts and reservoirs by the bite of sand fly insects (BANETH, 2006; SONODA et al., 2013).

Leishmaniasis can be classified as cutaneous, mucocutaneous and visceral, the last of which presents the greatest severity and being most fatal (WHO, 2010; MARCONDES et al., 2011). In this context, dogs may present either the cutaneous or the visceral form. In Brazil, canine visceral leishmaniasis (CVL) is caused by the protozoon Leishmania infantum (BANETH, 2006); the sand 
fly Lutzomyia longipalpis is the vector, and dogs are considered to be the main reservoir (GONTIJO \& MELO, 2004).

Although leishmaniasis was once considered to be a rural disease, it has been spreading in urban areas. There are growing numbers of human visceral leishmaniasis cases in major Brazilian metropolises, and $94 \%$ of these cases have been reported in the northeastern region. Migration of people, together with their dogs, fleeing poverty, malnutrition and poor housing conditions, situations of illiteracy, environmental changes (deforestation and construction of dams) and migration of nonimmune people to endemic areas all contributed towards the emergence of the disease in the northern, southeastern and central-western regions in 2000 (WHO, 2010).

In the state of São Paulo (Southeastern Brazil), the area of disease transmission has become larger since the disease was first introduced in 1998. Its introduction led to an epidemic in the region of Araçatuba, with a mortality ranging from 29.4\% (1999) to $9.3 \%$ (2010). Because of this situation, the Epidemiological Surveillance Center of the state of São Paulo devised an Index of Potential Risk of Human Visceral Leishmaniasis (IPRL). This index classifies municipalities in the state of São Paulo into two groups: silent (without confirmation of human cases or autochthonous canine cases) and transmission (with confirmation of human cases and/or canine autochthonous cases) (GOMES et al., 2013).

The clinical signs shown by dogs with CVL vary, but dermatological signs are commonly presented (MARZOCHI et al., 1985; BANETH et al., 2008; DIAS et al., 2008; SOLANO-GALLEGO et al., 2011; TOSCANO et al., 2013).

Diagnosis is complex, as the disease may mimic other illnesses. For this reason, it has to be based on clinical signs, the epidemiology of the disease and parasitological, serological, molecular and immunocytochemical tests (GONTIJO \& MELO, 2004; SOLANO-GALLEGO et al., 2011). The hepatic and renal profiles are important when the disease staging is determined (VIEIRA et al., 2011), since kidney disease may be the only clinical manifestation, advancing to nephrotic syndrome or chronic kidney disease (BANETH et al., 2008; DIAS et al., 2008).

Considering the severity of leishmaniasis in dogs and the zoonotic nature of the disease, the aim of this study was to report on the cases of six animals that presented autochthonous cases of canine visceral leishmaniasis and received care in Pedregulho, state of São Paulo, and, moreover, to emphasize the responsibility of government agencies sanitary to the epidemiological control of the disease and the importance of parasitological examination in the diagnosis.

\section{Materials and Methods}

This study was conducted with approval from and under surveillance by the Ethics Committee for Use of Animals of the University of Franca (UNIFRAN), state of São Paulo. Approval was granted on October 28, 2013, under protocol number 042/13.

Eleven dogs of various ages, breeds, gender and size were observed at home. They lived in a house by a river, near the edge of the reservoir of the Estreito hydroelectric plant, municipality of Pedregulho, state of São Paulo (38Km from Franca), which belongs to the Regional Health Department of Ribeirão Preto, state of São Paulo, and to the Epidemiological Surveillance Group of Franca, state of São Paulo. Eight of these animals were originally from the municipality of Franca, but they had lived at this place since they were puppies and did not have any history of trips. The other three were natives of Pedregulho.

The clinical signs presented by the patients started in a varied, chronic and insidious manner, over a period of approximately 6 months. Humans in contact with them did not show any apparent symptoms.

Taking into account the varied clinical signs, the number of sick animals and the environmental conditions, there was a suspicion of leishmaniasis. All the dogs were subjected to hematological tests and anesthetized for aspiration puncture of the bone marrow (sternum) and peripheral hyperplastic lymph nodes, for further parasitological investigation. Venous blood was also collected for serological qualitative tests (rapid immunochromatographic test) and quantitative tests (Enzyme-Linked Immunosorbent Assay - ELISA).

Since the suspicion of visceral leishmaniasis arose, the samples were sent to the Adolfo Lutz Institute, in Ribeirão Preto, state of São Paulo, which is accredited by the Ministry of Agriculture.

\section{Results and Discussion}

The Adolfo Lutz Institute - Government of the State of São Paulo confirmed the disease in six of the 11 dogs tested (55\%), through verification of the amastigote form of Leishmania in the bone marrow aspiration puncture (Figure 1). Following the confirmation, the institute recommended that new samples should be collected through lymph node and bone marrow puncture, in order to inoculate the material into a culturing medium in sterile saline solution with gentamicin. The results from the complementary tests are in Table 1.

Based on the results obtained, the presence of CVL was notified to the Epidemiological Surveillance Group of the municipality of

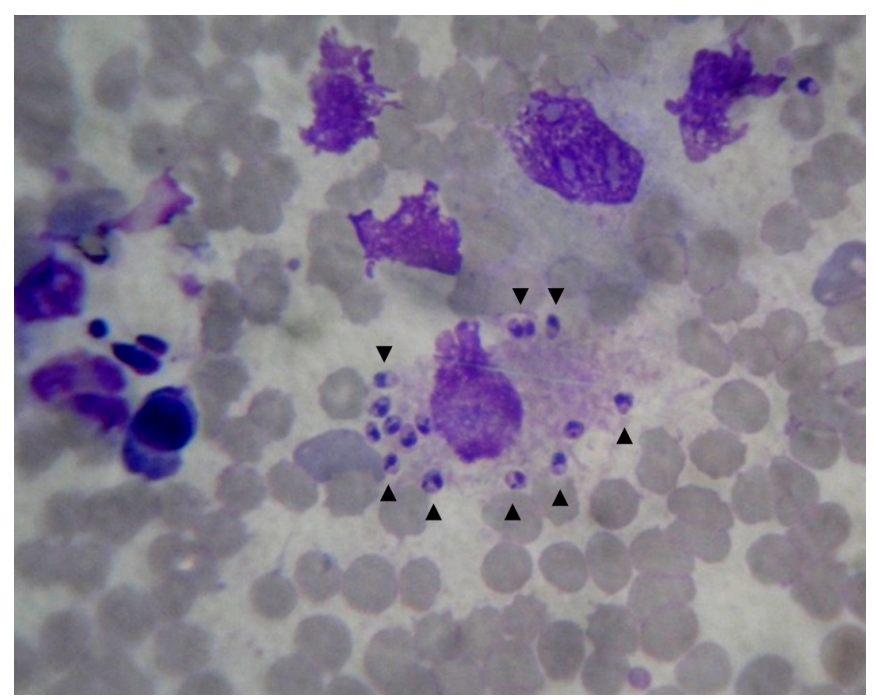

Figure 1. Photomicrograph of a canine bone marrow smear showing amastigote forms of Leishmania sp. (arrows). Source: personal archive. 
Table 1. Serological and parasitological complementary tests performed in order to diagnose canine visceral leishmaniasis in the eleven suspected dogs and the respective results.

\begin{tabular}{lcc}
\hline \multicolumn{1}{c}{ Complementary tests } & Results & Number of positive dogs \\
\hline $\begin{array}{l}\text { Serological tests } \\
\text { (immunochromatography) }\end{array}$ & reactive & 6 \\
$\begin{array}{l}\text { Serological tests (ELISA) } \\
\text { Parasitological tests } \\
\text { (bone marrow) }\end{array}$ & reactive & 6 \\
$\begin{array}{l}\text { Parasitological tests } \\
\text { (lymph nodes) }\end{array}$ & + & 6 \\
$\begin{array}{l}\text { Culturing for } \\
\text { Leishmania spp. }\end{array}$ & + & 2 \\
\hline
\end{tabular}

Franca, which contacted the agency in charge of local entomological research on the vector $L$. longipalpis, the Endemic Disease Control Superintendency of the state of São Paulo (SUCEN/SP). It is important to emphasize that the Brazilian Ministry of Health has recently reported that another species (Lutzomyia cruzi) has already been described in the state of Mato Grosso do Sul (BRASIL, 2013).

According to the Surveillance Program and SUCEN/SP, the region in which the dogs reported here lived had been classified by IPRL in May 2013 as silent, non-receptive and vulnerable to leishmaniasis (RANGEL et al., 2013). These six autochthonous cases of canine visceral leishmaniasis were diagnosed later on in the same year, but no data have so far been reported in the Boletim Epidemiológico Paulista (São Paulo Epidemiological Bulletin) for the year 2014, referring to the new classification of this region. No human cases and/or deaths have been reported by the Epidemiological Surveillance Center (which is part of the State of São Paulo Health Department), which confirms the reports made by Silva (2007), according to which canine cases precede human ones.

In humans, visceral leishmaniasis is endemic in 88 countries around the world, but notification is compulsory in only 32 of them. It is estimated that 500,000 new cases emerge every year, and that approximately 12 million people are currently infected (WHO, 2010). In Brazil, the disease is present in 22 out of the 26 states: 3,486 cases and 232 deaths were reported between the years 2010 and 2012 (DONATO et al., 2013) and, according to Rabello et al. (2003), the number of cases of coinfection with the human immunodeficiency virus has been increasing significantly. There have also been reports about illnesses that occur concurrently with leishmaniasis, such as ehrlichiosis, demodicosis and sarcoptic mange, hepatozoonosis and lymphoma (CIARAMELLA et al., 1997), and neosporosis and toxoplasmosis (ZULPO et al., 2012).

The region described in this study used to be considered rural until the Estreito hydroelectric plant started to be built. This caused deforestation and population growth in the adjacent village, to house power plant employees and other workers, along with construction of houses by the river (ranchos), thus making the area urbanized. These factors back up the reports by Rangel \& Vilela (2008) and by WHO (2010), which state that the speed of spreading of the disease is related to the impact of environmental changes promoted by man. They also corroborate the descriptions made by Lainson \& Rangel (2005), which claim that the sand fly vector has wild origins, but may have undergone changes in its feeding habits, secondarily to environmental changes, given that it was feeding on blood from various other vertebrate species, such as chickens, pigs and dogs, which shared the same space in the locality.

In the present study, the number of animals infected by leishmaniasis was relatively small in comparison with other studies (TOSCANO et al., 2013), but one must consider that the canine population surrounding the site described is approximately 107 animals, representing 5\% of prevalence. As suggested by Gontijo \& Melo (2004), dogs are considered to be the main reservoir of the visceral disease in humans, although other wild species have already been described hosting these protozoa.

According to Moreira et al. (2002), making the diagnosis in subclinically infected animals (i.e. those in which few forms of the protozoa are found in the tissues) is difficult and doubtful. Therefore, in these cases, it is suggested that tests with higher sensitivity should be used, like direct immunofluorescence and immunohistochemistry.

All the six dogs that were positive for leishmaniasis were put down, as ordered by the Epidemiological Surveillance Center of the municipality of Franca, given that treatment is still a matter of controversy (CASTRO et al., 2012).

\section{Conclusions}

The parasitological test of bone marrow was essential for the diagnosis of affected patients.

The place where the six autochthonous dogs were diagnosed with visceral leishmaniasis has not still been catalogued in the reports of the Health Surveillance Service of the State of São Paulo, and this may be significantly contributing towards the slow pace of taking measures to control the disease animal and human.

Given the exponential increase in the number of dogs reported to be positive for leishmaniasis across Brazil, ongoing investigation of this disease must be included in the differential diagnosis of other diseases of multisystemic nature. In addition, programs of mass media announcements should be drawn up in order to warn the population of the risks and to stimulate prophylaxis concerning the disease.

\section{References}

Baneth G, Koutinas AF, Solano-Gallego L, Bourdeau P, Ferrer L. Canine leishmaniosis - new concepts and insights on an expanding zoonosis: part one. Trends Parasitol 2008; 24(7): 324-330. http://dx.doi.org/10.1016/j. pt.2008.04.001. PMid:18514028

Baneth G. Leishmaniosis. In: Greene CE, editor. Infectious diseases of the dog and cat. 4th ed. Philadelphia: Elsevier Saunders; 2006. p. 734-748.

Brasil. Ministério da Saúde. Manual de vigilância e controle da leishmaniose visceral. Brasília; 2013. [cited 2013 Oct 05]. Available from: http://bvsms. saude.gov.br/bvs/publicacoes/manual_vigilancia_controle_leishmaniose_ visceral_1edicao.pdf. 
Castro IP, Sousa MVC, Magalhães GM, Mundim AV, Noleto PG, Paula $\mathrm{MBC}$, et al. Perfil hepático e protéico em cães com leishmaniose visceral. Biosci J 2012; 28(5): 799-804.

Ciaramella P, Oliva G, Luna RD, Gradoni L, Ambrosio R, Cortese $\mathrm{L}$, et al. A retrospective clinical study of canine leishmaniasis in 150 dogs naturally infected by Leishmania infantum. Vet Rec 1997; 141(21): 539-543. http://dx.doi.org/10.1136/vr.141.21.539. PMid:9413121

Dias EL, Batista ZS, Guerra RMSNC, Calabrese KS, Lima TB, AbreuSilva AL. Canine Visceral Leishmaniasis (CVL): Seroprevalence, clinical, hematological and biochemical finding of dogs naturally infected in an endemic area of São José de Ribamar Municipality, Maranhão State, Brazil. Cienc Anim Bras 2008; 9(3): 740-745.

Donato LR, Lima FEF Jr, Albuquerque R, Gomes MLS. Vigilância e controle de reservatórios da leishmaniose visceral no Brasil: aspectos técnicos e jurídicos. Rev Educ Cont Vet Med Zootec 2013; 11(2): 18-23.

Ferreira CE, Melo AL, Gontijo FMC. Leishmanioses do Novo Mundo. Cad Tec Vet Zootec 2012; 1(65): 9-27.

Gomes LH, Menezes RF, Vieira PA. Serviços Municipais de controle de zoonoses no Estado de São Paulo: diagnóstico situacional e indice de potencial de risco para a Leishmaniose Visceral Americana. 2013. [cited 2013 Nov 14]. Available from: http://www.saude.sp.gov.br/resources/ ccd/publicacoes/publicacoes-ccd/manuaisnormas-e-documentos-tecnicos/ pesquisa_ccz_completa.pdf.

Gontijo FMC, Melo MN. Leishmaniose Visceral no Brasil:quadro atual, desafios e perspectivas. Rev Bras Epidemiol 2004; 7(3): 338-349. http:// dx.doi.org/10.1590/S1415-790X2004000300011.

Lainson R, Rangel EF. Lutzomyia longipalpis and the eco-epidemiology of American visceral leishmaniasis, with particular reference to Brazil: a review. Mem Inst Oswaldo Cruz 2005; 100(8): 811-827. http://dx.doi. org/10.1590/S0074-02762005000800001. PMid:16444411

Marcondes M, Biondo AW, Gomes AAD, Silva ARS, Vieira RFC, Camacho AA, et al. Validation of a Leishmania infantum ELISA rapid test for serological diagnosis of Leishmania chagasi in dogs. Vet Parasitol 2011; 175(1-2): 15-19. http://dx.doi.org/10.1016/j.vetpar.2010.09.036. PMid:21030153

Marzochi MCA, Coutinho SG, Souza WJ, Toledo LM, Grimaldi G Jr, Momen H, et al. Canine visceral leishmaniasis in Rio de Janeiro, Brazil. Clinical, parasitological, therapeutical and epidemiological findings (1977-1983). Mem Inst Oswaldo Cruz 1985; 80(3): 349-357. http:// dx.doi.org/10.1590/S0074-02761985000300012. PMid:3837171
Moreira MAB, Luvizotto MCR, Nunes CM, Silva TCC, Laurenti MD, Corbett CEP. Aplicação da técnica de imunofluorescência direta para o diagnóstico da leishmaniose visceral canina em aspirado de linfonodo. BrazJ Vet Res Anim Sci 2002; 39(2): 103-106. http://dx.doi.org/10.1590/ S1413-95962002000200009.

Rabello A, Orsini M, Disch J. Leishmania/HIV co-infection in Brazil: an appraisal. Ann Trop Med Parasitol 2003; 97(Suppl 1): 17-28. http:// dx.doi.org/10.1179/000349803225002507. PMid:14678630

Rangel EF, Vilela ML. Lutzomyia longipalpis (Diptera, Psychodidae, Phlebotominae) and urbanization of visceral leishmaniasis in Brazil. Cad Saude Publica 2008; 24(12): 2948-2952. http://dx.doi.org/10.1590/ S0102-311X2008001200025. PMid:19082287

Rangel O, Hiramoto RM, Henriques LF, Taniguchi HH, Ciaravolo RMC, Tolezano JE, et al. Classificação epidemiológica dos municípios segundo o Programa de Vigilância e Controle da Leishmaniose Visceral Americana no Estado de São Paulo, para 2013. Bol Epidemiol Paul. 2013; 10(111): 3-14.

Silva FS. Patologia e patogênese da Leishmaniose Visceral Canina. Rev Tróp: Ciênc Agrár Biol 2007; 1(1): 20-31.

Solano-Gallego L, Miró G, Koutinas A, Cardoso L, Pennisi MG, Ferrer $\mathrm{L}$, et al. LeishVet guidelines for the pratical management of canine leishmaniosis. Parasit Vectors 2011; 4: 86

Sonoda MC, Rossi CN, Laurenti MD, Larsson CE. Estudo retrospectivo de casos caninos de leishmaniose atendidos na cidade de São Paulo, Brasil (1997-2007). Semina: Ciênc Agrár 2013; 34(2): 741-758.

Toscano CP, Rossi CN, Ribeiro VM, Laurenti MD, Larsson CE. Caracterização clínica e epidemiológica das leishmanioses em cães no Estado de São Paulo. Braz J Vet Res Anim Sci 2013; 50(2): 121-128. http://dx.doi.org/10.11606/issn.2318-3659.v50i2p121-128.

Vieira FA No, Sousa AKS, Marques MV, Arruda DS, Silva LA. Avaliação de parâmetros bioquímicos em cáes infectados por Leishmania chagasi. Rev Ciênc Saúde 2011; 13(2): 131-140.

World Health Organization - WHO. Control of the leishmaniases [online]. Geneva: WHO; 2010. WHO Technical Report Series. [cited 2013 Sept 22]. Available from: http://whqlibdoc.who.int/trs/WHO_TRS_949_eng.pdf.

Zulpo DL, Leite JHAC, Cunha IAL, Barros LD, Taroda A, Camargo VE Jr, et al. Ocorrência de anticorpos contra Leishmania spp., Neospora caninum e Toxoplasma gondii em soros de cães atendidos no Hospital Veterinário da Universidade Estadual de Londrina-Pr. Semina: Ciênc Agrár 2012; 33(5): 1897-1906 